\title{
Diliçi Çeviriler, Yanmetinler ve Normlar Odağında Tarihsel Roman Çevirileri: The Talisman Örneği*
}

\section{Translation of Historical Novels with a Focus on Intralingual Translations, Paratexts and Norms: The Case of The Talisman}

Araştırma/Research

\section{Nilüfer ALIMEN}

Dr. Öğr. Üyesi, İstanbul 29 Mayıs Üniversitesi, Edebiyat Fakültesi, Mütercim ve Tercümanlık Bölümü, nalimen@29mayis.edu.tr, ORCID ID: orcid.org/0000-0002-1993-8918

\section{ÖZET}

Bu makalenin amacı, İskoçyalı yazar Sir Walter Scott'ın The Talisman (1825) adlı romanının Türkçedeki çeviri macerasını irdelemektir. Dünya edebiyatında, tarihsel romanın kurucu figürü olarak karşımıza çıkan Scott'ın İngilizce kaleme aldığı The Talisman ilk olarak 1912 yılında Fransızca aradilden Osmanlı Türkçesine Mehmed Halid tarafından çevrilmiş, bu çevirinin diliçi çevirileri ise yaklaşık yüz yıllık bir süre boyunca Türkiye'deki farklı yayınevlerince yayımlanmıştır. The Talisman'ın Türkçedeki çeviri macerasını tarihsel bağlam içinde irdelemeyi amaçlanan bu çalışma çerçevesinde, toplam 11 çeviri eserden oluşan bir bütünce derlenmiş; bütüncenin "çevirinin doğrudanlı̆̆ı" (Toury, 1995/2012) açısından yapılan ön incelemesi sonucunda çevirilerin tamamının aradilden çevrildiği veya diliçi çeviri yoluyla aktarıldığı saptanmıştır. Bütüncede yer alan çevirilerde gözlemlenen yoğun yanmetin kullanımı gerekçesiyle yanmetin (Genette, 1997) odağıyla yürütülen betimleyici incelemenin sonucunda, yanmetinsel öğelerde Doğu ve Batı arasındaki gerilimin güçlü izdüşümlerine rastlanmıştır. Yanmetinlerin, Doğunun Batı karşısındaki konumu, Türklük vurgusu ve "tarihsel gerçeklik" konularında çeviri sürecindeki eyleyenlerin hassasiyetlerini ve müdahalelerini yansıttıkları gözlemlenmiş, dolayısıyla hem eyleyenlerin yanmetin kullanımı aracılı̆̆ıyla görünür hale geldikleri hem de tarihsel roman çevirisi bağlamında "çevirmen"-"yazar" ve "kurgu"-"gerçeklik" arasındaki sınırların bulanıklaştığının söylenebileceği ileri sürülmüştür. Yanmetinsel öğelerin kullanım işlevleri ile ilgili söz konusu tespitler bağlamında, yüz yıllık süre boyunca dillerarası çeviriye gereksinim duyulmamasının nedeninin, yanmetinlerle konumlandırılarak erek-dizgede onanmış belirli bir işlev üstlenen bir metnin toplumda bu konudaki uzmanlıklarıyla kabul görmüş uzmanlar tarafından hâlihazırda üretilmiş ve sürekli

* 12-13 Nisan 2019 tarihinde Kırklareli Üniversitesi'nde düzenlenen II. Uluslararası Rumeli [Dil, Edebiyat, Çeviri] Sempozyumu'nda sunulan "Walter Scott'ın The Talisman Romanının Türkçe Çevirileri Üzerine Bir İnceleme" başlıklı bildirinin gözden geçirilmiş ve genişletilmiş halidir. 
yeniden-üretiliyor olmasından kaynaklandığı öne sürülmüştür. Sonuç olarak, bu çalışmanın, tarihsel roman çevirisi bağlamında, çevirinin doğrudanlığına ilişkin normlar ile erek-dizgedeki eyleyiciler tarafından çeviri metne yüklenen işlev arasındaki ilişkiyi yanmetin odağıyla tarihselleştirdiği ve örneklendirdiği iddia edilmiştir.

Anahtar Sözcükler: Walter Scott, The Talisman, tarihsel roman, yanmetin, çeviri normları, çevirinin doğrudanlığı, diliçi çeviri

\begin{abstract}
This article aims to examine the translation adventure of The Talisman (1825) by Scottish author Sir Walter Scott, who is recognized as the founding figure of historical novel in world literature, in Turkish. It was first translated from French, a mediating language, into Ottoman Turkish in 1912 by Mehmed Halid. Its intralingual translations were published by different publishing houses in Turkey for about a century. This study aims to scrutinize The Talisman's translations within the historical context and through a compiled corpus of 11 translated works. The preliminary examination of the corpus in terms of "directness of the translation" (Toury, 1995/2012) has revealed that all translations were translated from a mediating language or were intralingual translations. Since paratexts are commonly used, a descriptive analysis focusing on paratexts (Genette, 1997) has been carried out and several manifestations of the tension between the East and the West have been observed in the paratexts which reflect the sensitivities and interventions of the translation agents concerning the position of the East against the West, the emphasis on Turkishness, and "historical reality". It has thus been argued that the lines between "translator""writer" and "fiction"-"reality" are blurred in the present case where the agents become visible through paratexts. Based on the functions of paratextual elements, it has been argued that interlingual translation was not needed for a century thanks to the availability of a constantly reproduced text by widely acclaimed experts and to the fact that the source text was positioned in the target system through paratexts serving a certain function that was already approved by the target reader. In conclusion, within the context of historical novel translation, the study has been claimed to historicize and exemplify the relationship between the norms regarding the directness of translation and the function attributed to translation by the agents in the target system.
\end{abstract}

Keywords: Walter Scott, The Talisman, historical novel, paratext, translational norms, directness of translation, intralingual translation

\title{
1. Giriş
}

Bu makalenin amacı, dünya edebiyatında "tarihsel roman" türünün modern anlamda ilk eserini kaleme aldığı ve bu türün "babası" ya da "kurucusu" (Krş. Halim Kara, 2017, s. 8; Turgut Göğebakan, 2004, s. 16) olduğu kabul edilen İskoçyalı yazar Sir Walter Scott’ın The Talisman (1825) adlı romanının Türkçedeki diliçi ve dillerarası çeviri macerasını irdelemektir. Yazarın, "Waverley Novels" ("Waverley Romanları") olarak adlandırılan ve 1814-1832 yılları arasında kaleme aldığı serinin "Tales of the Crusaders" ("Haçlıların Öyküleri") başlıklı alt serisinde, Haçlı seferlerini konu alan The Bethrothed (1825) ve The Talisman (1825) romanları yayımlanmıştır. İslam tarihinin önemli figürlerinden biri olan Selahaddin Eyyubi'nin Haçlı seferleri sırasında İngiltere Kralı I. Richard'la karşılaşmasını konu alan The Talisman adlı eser ise hem Osmanlı hem de Cumhuriyet dönemlerinde farklı yayınevleri tarafından, farklı çevirmenlerin kaleminden yayımlanmıştır. 
Çalışmanın bütüncesi, Mihran Matbaası (1912), Maarif Kitaphanesi (1934, 1942, 1949, 1953, 1964), Ötüken Neşriyat (2012, 2013, 2020) ve Timaş Yayınevi (1995) tarafından yayımlanan toplam 11 eserden oluşmaktadır. The Talisman'ın Türkçedeki ilk çevirisi Mehmed Halid tarafından Fransızcadan yapılmış ve 1910 yılında yayımlanmıştır. Mehmed Halid'in Osmanlı Türkçesine ${ }^{1}$ çevirisi önce Sabah gazetesinde tefrika olarak, 1912 yılında ise Selahaddin-i Eyyubî ve Arslan Yürekli Rişar: Ehl-i Salib Vukuatına Müstenid Tarihî Roman başlığıyla kitap olarak yayımlanmıştır.

Söz konusu çevirinin diliçi çevirileri 1995-2020 yılları arasında çeşitli yayınevleri tarafından basılmıştır. Dursun Gürlek'in diliçi çevirisi Timaş Yayınevi tarafından 1995 yılında Selahaddîn-i Eyyûbî ve Arslan Yürekli Rişar başlığıyla yayımlamış, kitabın iç kapağında "Osmanlıca'ya Tercüme: Mehmed Halid” ve “Osmanlıca'dan Sadeleştiren: Dursun Gürlek" ifadeleri yer almıştır. Halid'in çevirisi günümüz Türkçesiyle Ötüken Neşriyat tarafından da basılmıştır. Erol Kılınç'ın diliçi çevirisini yaptığı metin 2012 yılında Selahaddin Eyyubî ve Arslan Yürekli Richard (3. Haçlı Seferinin Filistin Safhasının Romanı) başlığıyla yayımlanmış, 2013 ve 2020 yıllarında yeniden basılmıştır. Söz konusu baskılarda Erol Kılınç “yayına hazırlayan" olarak sunulmuş ve "Türkçesi: Mehmed Halid" ifadesine yer verilmiştir. Çalışmanın bütüncesini oluşturmak üzere, Maarif Kitaphanesi'nin farklı yıllarda yayımladığı altı çeviriye erişilmiş ve bu metinler de bütünceye dâhil edilmiştir. Söz konusu yayınevinin 1934 yılında yayımladığı metinde kaynak metnin adını ve yazarını belirtmediği, 1942-1956 yılları arasında aynı kapak görselini kullandıkları ve "Ingiliz Muharriri Valter Skot'dan" ibaresine kitabın ön kapağında yer verdiği (Bkz. Ek 3), 1964 baskısında ise yazarın iç kapakta "Walter Scott" olarak belirtildiği saptanmıştır (Bkz. Ek 6). Ancak sözü edilen yayınevinin metinlerinden hiçbirisinde çevirmen adı ve kaynak metnin başlığı belirtilmemiştir.

Bütüncenin "çevirinin doğrudanlığı" (Toury, 1995/2012) açısından yapılan ön incelenmesi sonucunda, Türkiye'de yayımlanan çevirilerden yalnızca birinin İngilizce kaynak metinden çevrildiği, diğer metinlerin aradilden çevrildiği/diliçi çeviri yoluyla aktarıldığı saptanmıştır. Çalışmaya konu olan diliçi ve dillerarası çevirilerde gözlemlenen yoğun yanmetin kullanımı gerekçesiyle ilgili çevirileri yanmetin (Genette, 1997) odağıyla inceleyen bu çalışmanın cevap aradığı sorulardan biri, İngilizce bir metin olan The Talisman'ın yaklaşık yüz yılık bir süre boyunca neden Fransızca aradilden yapılan dillerarası çevirisinin diliçi çevirileriyle Türk okurlarına sunulduğudur. İkinci soru, Haçlı seferlerini konu alan, tarihsel roman türündeki bu eserin çevirilerindeki yanmetinlerde, Doğu-Batı ilişkisinin/geriliminin yansımalarının izinin sürülüp sürülemeyeceğidir. Bir başka soru ise, tarihsel roman çevirisi ve tarihsel gerçeklik bağlamında çevirmen-yazar ilişkinin dinamikleri ile "kurgu" -"gerçeklik" ikili karşıtlığının nasıl işlediğidir.

Söz konusu sorulara cevaplar aramak amacıyla, çalışmanın bu bölümünde, Scott'ın hayatı ve eserlerinin yanı sıra tarihi roman türü hakkında genel tartışmalara ve görüşlere değinilecektir. Aynı zamanda The Talisman'ın Osmanlı ve Cumhuriyet dönemlerinde yayımlanan Türkçe çevirileri hakkında bilgi verilecek, Türk yazarların/araştırmacıların Scott hakkındaki görüşleri sunulacaktır. İkinci bölüme

${ }^{1}$ Çalışmanın devamında Osmanlıca olarak anılacaktır. 
çalışmanın yöntemsel ve kuramsal çerçevesi açıklanacaktır. Üçüncü bölümde, çalışmanın bütüncesini oluşturan çevirilerin yanmetinsel öğeleri, "Doğu-Batı ilişkisi”, "tarihsel gerçeklik", "Türklük vurgusu" ve "çevirinin doğrudanlığı" başlıkları altında incelenecektir. Dördüncü bölümde inceleme sonuçları tartışılacak ve beşinci bölümde ise sonuç gözlemlerine yer verilecektir.

\subsection{Tarihsel Roman}

Tarihsel romanın çıkış tarihinin XIX. yüzyılın başlarına rastladığını belirten Macar filozof, siyaset bilimci ve edebiyat bilimcisi György Lukács, bu türün Napolyon'un yenilgiye uğradığı dönemde ortaya çıktığını belirtmiştir. Lukács'a göre, her ne kadar 17. ve 18. yüzyıllarda da tarihsel konuları ele alan pek çok roman yazılmış olsa da Scott'ın 1814 yılında yayımlanan Waverley adlı eseri, modern anlamda ilk tarihsel romandır. Lukács, sözü edilen yüzyıllarda yayımlanan tarihsel romanları "sözde tarihsel roman" (s. 31) olarak adlandırmış ve bu romanların sadece "görünürdeki konuları" ve "kostümleri" bakımından tarihsel olduğunu öne sürmüştür (s. 21).

Turgut Göğebakan (2004), hem Fransız Devrimi'nin etkisiyle ortaya çıkan ulusçuluk akımının bir "moda" haline gelmesi hem de "Napolyon işgallerinin uyandırdığı intikam duygusu"nun bir sonucu olarak türün ilk örneğinin ortaya çıktığı 19. yüzyılı tarihsel romanın "en parlak dönemi" olarak nitelendirmiştir (s. 19). Romanı "bir tarihî evrimin ürünü" olarak tanımlayan Taner Timur (1991), romanın kendisinin aynı zamanda "bu tarihi yansıttığını ve bir ölçüde de etkilediğini" öne sürmüştür (s. 194). Robert Meyer (2017) ise en az Lord Byron ve Napolyon kadar meşhur olduğunu ve olağanüstü yeteneklere ve başarılara sahip olan eşsiz bir yaratıcı olarak nitelendirildiğini söylemiştir. Scott'ın kimliklerini inşa etmek ya da dünyada kendi yolunu çizmek isteyen kişilere, tıpkı Byron gibi, rehberlik ettiğini belirtmiştir (s. 26). Hem eserlerini ürettiği zaman diliminde yaşayan kişiler ve olaylardan etkilenen hem de okurları üzerinde de büyük bir etki yaratan yazarın romanlarında tarihsel gerçekliğin ne derece söz konusu olduğu üzerine pek çok tartışma yer almaktadır.

\subsection{Walter Scott romanlarında "tarihsel gerçekçilik"}

John H. Alexander, Walter Scott's Books: Reading the Waverley Novels (2017) başlıklı kitabında The Talisman'ı da içeren "Waverley Romanları" serisini incelemiştir. Scott romanlarının açıklamalı ve düzeltilmiş edisyonlarından oluşan ve David Hewitt'in editörlüğünde yayımlanan "Edinburgh Edition of the Waverley Novels" serisinde belirtildiği ve Alexander'ın aktardığı üzere, yazarın tarihsel olaylar için kaynak metin olarak kullandığı beş metin özellikle ön plana çıkmaktadır. Bunlar Edward Gibbon'ın The History of the Decline and Fall of the Roman Empire, Henry Weber'in Tales of the East, Barthélemy de Molainville d'Herbelot'nun Bibliotheque Orientale, Robert Henry'nin The History of Great Britain, Charles Mills'in The History of the Crusades for the Recovery and Possession of the Holy Land kitapları olarak sıralanmış, ayrıca Doğulu metinlerin çevirilerinden ve çağdaş edebiyatta Doğu'ya atfedilen hayali yaklaşımlardan yararlanılmıştır (s. 186). Bu bağlamda, Scott'ın romanlarında kullandığı özdeyiş ve atasözlerinden söz edilebilir. Scott'ın kullandığı atasözlerinden bahseden Alexander, bunların Doğulu kaynaklardan, Gibbon veya d'Herbelot gibi yazarların metinlerinden ve 
aslen Batı kökenli olan özdeyişlerin "çevirilerinden” oluştuğunu belirtmiştir. Örneğin, The Talisman'da yer alan "the Eastern proverb, that the sick chamber of the patient is the kingdom of the physician" (1825, s. 83) ("Bir Doğu atasözü der ki, hastanın odası doktorun krallığıdır") ve "the tattered robe makes not always the dervise" (s. 140) ("her yırtık cübbe giyen derviş olmaz") gibi ifadeler aslen Doğu kökenli olmamasına rağmen Scott tarafından Doğu'ya atfedilen atasözleridir. Bu örneklerin yanı sıra, Alexander'a göre, romanın başkahramanlarından Selahaddin İncil ve Kur'an-ı Kerim'i bir araya getiren veya İncil'i ve Samuel Richardson'ın Clarissa eserini hatırlatan ifadeler kullanmaktadır. Buna karşın, Scott’ın özgün Doğulu atasözlerini de kullandığı belirtilmiştir (s. 186).

Andrew Lincoln, Walter Scott and Modernity (2007) adlı kitabında Scott'ın romanlarını kaleme aldığı dönemde geçmişteki Doğu kültürüne duyulan saygının yerini Hristiyanlığın daha üstün olduğu iddiasının aldığını ve Haçlı Seferi'nin her iki tutumun da ortak noktası olduğunu belirtmiştir. Buna ek olarak, İskoç tarihçi William Robertson'ın haçlı seferlerinin Doğu kültürünün Avrupa Hristiyanlığı üzerinde "barbarlığını ve cehaletini" ortadan kaldırması bakımından önemli bir etkisi olduğu yönündeki görüşüne de yer vermiştir (s. 106).

Türk araştırmacı ve akademisyenler tarafından bu konuda yapılan araştırmalara bakıldığında yazarın tarihsel olaylardan hareketle romanlarını şekillendirdiği anlaşılmaktadır. Örneğin Taner Timur, Scott’ın romanlarında İngiliz ulusunun 400 yıllık oluşum serüvenini ele aldığını ve Scott'a göre bu ulusun Norman istilasından sonra Saksonlar ve Normanlar'ın sentezlenmesiyle ortaya çıktığını belirtmiştir (1991, s. 195-6). Bununla birlikte, yazarın tarih bilgilerinin sağlam bir temele dayanmadığını ve profesyonel tarihçilerin romanlarında çeşitli maddi hatalar tespit ettiğini öne sürmüş ve ıvanhoe romanında Norman-Sakson bütünleşmesi bağlamında hatalar yaptığını şahsen açıkladığını eklemiştir (s. 196).

Edward Said ise Scott'ın İslam dinine ilişkin herhangi bir uzmanlığı olmadığını belirtmiş ve Scott'ın aksine bir İslam uzmanı olarak andığı H. A. R. Gibb'in yazarı İslam dini ve Selahaddin Eyyubi'ye dair "derin kavrayışından ötürü" yücelttiğini de vurgulayarak "iblis'e müminlerin kahramanı rolünü" vermiş olmasını "büyük bir sorumsuzluk" olarak nitelendirmiştir (1978/2017, s. 112).

Mina Urgan, Scott'ın Avrupa tarihi hakkında bilgi sahibi olduğunu belirtmiş ve romanlarında tarihsel olayları ele alış biçimini aşağıdaki gibi tanımlamıştır:

Serüvenleri ve eylemleri ele alırken, canlanan Scott, duygusal ilişkileri anlatmaya kalkınca, ayrıca başarısızığa uğradı. Üstelik, demin dediğimiz gibi, Avrupa tarihini iyi bilmekle birlikte, tarihsel olayları ve kişileri derinliğine algılayamadığı için, tarihe bakışında da yüzeysellikten kurtulamadı. Geçmişi biçimlendiren insanların ve kurumların -örneğin Katolik Kilisesi'nin- etkisini değerlendiremedi. Tarihi ancak öykülerine uygun zengin ve renkli bir dekor olarak gördü çoğu zaman. Ne var ki, kusurlu ya da eksik yanlarına karşın, tarihsel roman alanında ilk önemli yazar olduğu için, İngiliz edebiyatındaki yeri yadsınamaz gene de. $(2003 / 2020$, s. 714$)$ 
Urgan da Said'e benzer bir şekilde Scott'ın tarihsel olayları romanlarında ele alış biçimini eleştirse de bir noktada edebiyat dünyasında oynadığı kilit rolü yadsımamıştır.

Nitekim Scott'ın da tarihsel gerçeklik bağlamında olayları olduğu gibi aktarma veya kendini bir tarih uzmanı olarak konumlandırma gibi iddialarının olmadığını söylemek mümkündür. Bu önermeyi desteklemek için Ivanhoe (1820) romanına yazdığı önsöz örnek olarak gösterilebilir. David Brown'ın (1979/2016) aktardığı üzere, Scott önsözünde geçmişin "eksiksiz", "doğal” bir biçimde yeniden üretilmesinin imkânsız olduğunu belirtmiş ve tarihsel romanda ele alınan konunun yaşadığımız çağın davranışlarına ve diline "çevrilmesi" gerektiğini vurgulamıştır (s. 211). Yazarın tarihsel olayları romanlaştırılması sürecini bir "çeviri" eylemi olarak nitelendirmesi dikkat çekicidir.

Yakup Çelik, "Tarih roman ilişkisi-tarihi romanda kişiler" (2002) başlıklı makalesinde tarihsel gerçekliğin romanın üretilme sürecinde birtakım evrelerden geçtiğini öne sürmüştür. Çelik'e göre insanlar "sübjektif karakterler" olarak tanımladığı tarihi olayları tarihçinin yorumları üzerinden takip etmek zorundadır. Tarihçinin "tarihsel olmayan kurguya dayalı insan faktörünü ve onun yine tarihe konu olmayacak çevresini" yerleştiren roman yazarının böylelikle romanı ortaya çıkardığını belirtmiştir (2002, s. 110). Çelik'in tarihi romanın inşasına dair bu tespitleri ve Scott'ın romanlarıyla ilgili yukarıda belirtilen görüşlerden hareketle doğası gereği kurgulanmış metinler olan tarihi romanlarda "gerçeklik"ten pek de söz edilemeyeceği iddia edilebilir.

Benzer bir durum, Fransız yazar Alphonse-Marie-Louis de Lamartine'in L'Histoire de la Turquie (1854-59) adlı eserinin Türkçe çevirilerinde tespit edilmiş ve Ayşe Banu Karadağ (2012) tarafından çeviribilim açısından incelenmiştir. Bu incelemesinde Karadağ, "tarihyazımı ve çeviribilim ilişkisine yönelik bir bakış açısı geliştirilmesi gerektiğinin" altını çizmiştir. Karadağ, tarihyazımının "belli bir kurgu üzerine" temellendirildiğini ve "kurgu" kavramının yaptığı ilk çağrışımın "edebiyat" olduğunu belirtmiştir. Ancak tarihyazımının, edebiyatın aksine, yaşanmış bir olayı anlatmak zorunda olduğunu açıklamıştır. Karadağ’a göre, tarihyazımında yaşanmış bir olgunun temel alınması gerekirken, çeviride, bir kaynak metinden yola çıkılmak zorunda olunması önem taşımaktadır. Bu bağlamda, tarihyazımında yaşanmış olgunun tümüyle "tarafsız" bir biçimde kaleme alınmasının neredeyse imkânsız olduğu, tarihi yazan kişinin "kültürel ve ideolojik öğelerle şekillenen dünya görüşünün" bilgi aktarımında belirleyici olabileceği vurgulanmıştır. Bu çerçevede tarihyazımı ve çevirinin ideolojik söylemler olduğu ve "görecelik ortak paydasında" iki alanın "birleştiği" iddia edilmiştir. Bu iddianın çarpıcı yanı, tarihyazımının, bir tarihi olayı, aynı bir çeviri gibi, kendine bir kaynak metin olarak çıkış noktası almasıdır; bu durum, tarihyazımının bir çeviri türü şeklinde metin yorumlamasına imkân vermektedir. Bu görüş bağlamında Karadağ, anılan Türkçe çevirileri incelemiş ve çevirmen ve/veya redaktörün erek metinlerde Osmanlı tarihini dipnotlar aracılığıyla "yeniden yazdığını” öne sürmüştür (s. 244).

\subsection{Türk edebiyat dizgesinde Selahaddin Eyyubi ve Walter Scott}

Makalenin inceleme nesnesini oluşturan The Talisman'ın çeviri yoluyla Türk edebiyat dizgesine girişi ve tarihsel süreçteki serüvenini açıklamak için öncelikle Namık Kemal'in 
Selahaddin Eyyubi üzerine yazdığı biyografiden bahsetmek gerekir. Yazarın sözü edilen biyografiyi kaleme almadan önce Mukaddeme-i Celâl adlı eserinde roman türüne ilişkin görüşlerine yer verirken Scott'ı da andığı görülmektedir:

Avrupalılar roman yolunu o derece ileri götürmüşlerdir ki, bugün her mütemeddin milletin lisanında ahlâkça ve hatta bir dereceye kadar maarifçe istifâde olunacak binlerce hikâye bulunabilir. Hele içlerinde Walter Scott gibi, Charles Dickens gibi, Victor Hugo gibi, Alexandre Dumas gibi meşahirin bâzı hikâyeleri şu asrı medeniyete medar-ı mübahat olan âsâr-ı muhallededen addolunmaktadır. $(1305 / 1889$, s. 18)

Namık Kemal'in “övünme sebebi olan kalıcı eserler” üreten yazarlardan olarak tanımladığı, dünya edebiyatı klasikleri arasına giren eserleri okurlara kazandıran ünlü yazarların isimlerini sıralarken öncelikle Scott'ın ismine yer vermiş olmasını da dikkat çekici olarak değerlendirmek mümkündür. Fransız, Alman ve Rus edebiyatının önde gelen isimlerinin roman kurgularını ve tekniklerini Scott'tan ödünç aldıkları söylenmektedir (krş. Göğebakan, 2004, s. 17). Bu noktada Namık Kemal'in sözü edilen biyografisiyle ilgili Şerif Mardin'in Yeni Osmanlı Düşüncesinin Doğuşu (1962/1996) başlıklı kitabında aktardığı tespitlere yer vermek gerekmektedir:

Bir İslâm kahramanı olan Salahaddin'in hayatı ve zamanı hakkında kitap yazılması arzusu tamamiyle tesadüfî değildi. İslâm ümmetinin yeniden dirilişi düşüncesi gündemde idi ve Yeni Osmanlılar arasında bile akis bulmuştu. Şimdi Yeni Osmanlılar, Müslümanların siyasî birliği ile ilgili daha geniş bir teori üzerinde çalışmaya başlamışlardı. (s. 71)

Gültekin Yıldız (1998), sözü edilen biyografide Namık Kemal'in Selahaddin'i Osmanlı okurlarına "mazi olarak değil, hal ve istikbali için de elzem bir ideal idareci olarak" sunduğunu tespit etmiştir (s. 282). Yıldız, öncesinde Osmanlı tarihinde ismi pek de anılmayan Selahaddin'in, bu biyografinin yayımlanmasının ardından hem Osmanlı toplumu hem de entelektüelleri arasında İslam tarihinin en popüler ismi haline geldiğini öne sürmüştür (s. 283). Selahaddin'in popülaritesi Arap coğrafyasına kadar ilerlemiş ve sözü edilen dönemde "Avrupalı güçlerin ve Siyonistlerin artan müdahaleleri" karşısında benzer bir mücadeleyi yüzyıllar önce vermiş olan bu liderin çağdaş Arap entelektüelleri arasında oldukça ünlenmesiyle sonuçlanmıştır (s. 286).

Selahaddin'in, Namık Kemal'in biyografisinin etkisiyle, yeniden gündeme gelmesi ve popüler olması, Osmanlı döneminde kendisini konu alan telif ve tercüme eserlerin yayımlanmasıyla sonuçlanmıştır. Yıldız’ın (1998) belirttiği üzere İbrahim Rıfat Hilmizâde Salâhaddîn Eyyûbî (1326) başlıklı bir telif eser yayımlamış, Zegi Magamez ise Corcî Zeydân'ın Eyyubi'nin hayatını konu alan romanının çevirisini Salâhaddîn Eyyûbî ve ismâ'ilîler (1927) başlığıyla yayımlamıştır (s. 286). Bir diğer eser ise, bu çalışmanın çıkış noktasını oluşturan ve Türk edebiyat dizgesinde 100'ü aşkın yıl boyunca diliçi çeviri yoluyla yeniden okurlara sunulan, Mehmed Halid'in The Talisman çevirisidir. Bu noktada romanın Türk edebiyat dizgesindeki diliçi ve dillerarası çeviri serüvenini ele alırken öncelikle bu iki çeviri türüne dair tanımlara ve edebiyat ve çeviri tarihimizde diliçi çevirinin oynadığı role yer verilecektir. 


\subsection{Türk Edebiyat Dizgemizde The Talisman'ın Dillerarası ve Diliçi Çevirileri}

Roman Jakobson (1959/2012) çeviriyi diliçi, dillerarası ve göstergelerarası olmak üzere üç kategoriye ayırmış ve diliçi çeviriyi "dilsel göstergelerin aynı dilin başka göstergeleri aracılığılla yorumlanması" olarak, dillerarası çeviriyi ise "dilsel göstergelerin başka bir dil aracılığıyla yorumlanması" olarak tanımlamıştır (s. 62). Çeviribilim alanında Jakobson'un "gerçek anlamda çeviri" olarak da adlandırdığı dillerarası çeviriyi ele alan pek çok çalışma yer almış ve yine Jakobson'un "açımlama" olarak da adlandırdığı diliçi çeviriler görece daha geri planda kalmışır. Bunun bilincine varan çeviribilimciler bu kavramla ilgili tanımları genişletmiş ve diliçi çeviri vakaları üzerine çalışmalar yürütmüştür. Karen Korning Zethsen ve Aage Hill-Madsen (2016) diliçi çevirilerin aynı dil dizgesi içindeki lehçe, zaman dilimi, işlev gibi farklılıklardan meydana gelen engelleri aşmak için kullanılan bir yeniden yazma eylemi olduğunu belirtmiştir (s. 693). Günlük hayatta pek çok diliçi çeviri örneğiyle karşılaştığımızın altını çizen Zethsen, her ne kadar çeviri olarak alımlanmasa da çocuk okurlar için sadeleştirilen metinler, işitme engelliler için hazırlanan altyazılar, klasik eserlerin yeni çevirileri gibi pek çok diliçi çeviri örneğiyle günlük hayatımızda karşılaştığımızı (2007, s. 281), ancak yine de diliçi çevirilerin ikinci planda kaldığını öne sürmüştür (2009, s. 797).

Türkiye'de 1928 yılında Latin alfabesini kullanmaya başlaması ve dilin sadeleştirilmesi nedeniyle diliçi çeviri örnekleriyle sıkça karşılaşılmaktadır. Ancak her ne kadar Osmanlıca yazıımış bir telif romanının günümüz Türkçesine diliçi çeviri yoluyla aktarılması gibi örneklere edebiyat dizgemizde yaygın olarak karşılaşılsa da dillerarası bir çevirinin diliçi çeviri yoluyla günümüz okuruna aktarılması pek de sık rastlanılan bir durum değildir.

Bu çalışmada- Jakobson'un kategorilerinden ve tanımlarından yola çıkılarakThe Talisman'ın İngilizceden yapılan çevirileri dillerarası, Osmanlıcadan günümüz Türkçesine yapılan çevirileri ise diliçi çeviri olarak ele alınmaktadır. Çalışmanın bütüncesini oluşturan, 20. yüzyılın başlarından günümüze dek Türk okurlarına sunulmuş ve hâlihazırda yeniden yayımlanarak sunulmakta olan çevirilerin diliçi çeviri olması ve yalnızca bir tanesinin aradilden yapılmış dillerarası çeviri olması dikkat çekicidir.

Özlem Berk Albachten, Türk kültüründe eski edebiyat metinlerinin diliçi çeviri yerine "sadeleştirilmiş", "Türkçeleştirilmiş", "düzenlenmiş" veya "yayına hazırlanmış" olarak adlandırıldığına, bununla birlikte pek azının çeviri olarak anıldığına veya kabul edildiğine dikkat çekmiştir $(2013,258)$. Aslı Kalem Bakkal benzer bir durumun Nutuk'un diliçi çevirilerinde de gözlemlendiğini ve çevirmenlerin "düzenleyen", "günümüz Türkçesine özetleyerek aktaran", "günümüz Türkçesine uyarlayan" gibi adlandırmaların da farklı yayınevleri tarafından tercih edildiğini belirtmiştir (2019, s. 87). Bu çalışmada incelenen, Timaş ve Ötüken yayınevleri tarafından yayımlanmış diliçi çevirilerde de Gürlek ve Kılınç "çevirmen" olarak anılmadığı gözlemlenmiştir. Çevirmenler Timaş Yayınevi'nin yayımladığı diliçi çevirinin iç kapağında "Osmanlıca'ya Tercüme: Mehmed Halid" ve "Osmanlıca'dan Sadeleştiren: Dursun Gürlek", Ötüken Neşriyat'ın yayımladığı diliçi çeviride ise "Yayına Hazırlayan: Erol Kılınç" ve "Türkçesi: Mehmed Halid" ifadeleriyle belirtilmiştir. 
Maarif Kitaphanesi, Selahaddin'in Aslan Yürekli Richard'la maceralarını konu alan ve Scott'ın metnini kaynak olarak aldığını iddia eden veya kaynak metni, yazarı ve çevirmeni belirtilmemiş olan çeşitli kitaplar yayımlamıştır. Yayınevinin 1934, 1942, 1949, 1953, 1956 ve 1964 yıllarında yayımladığı altı metne erişilmiş ve çalışmanın bütüncesine dâhil edilmiştir. Maarif Kitaphanesi'nin 1934 yılında formalar halinde yayımladığı 12inci asırda Salip Muharebeleri: Salâhaddini Eyyubi ve Arslan Yürekli Rişar başlıklı eserin Cumhuriyet Dönemi'nde yayımlanan ilk Scott çevirisi olduğunu söylemek mümkündür. Ancak bu kitapta kaynak metin, yazar veya çevirmen ismi bulunmamaktadır. Bu noktada Scott'ın ilk roman serisi Waverley'i isimsiz olarak yayımladığına da dikkat çekmek gerekir. Gerard Genette'in belirttiği üzere, saygın bir hukukçu ve şair olarak tanınan Scott, sonraki romanlarında "Waverley'nin yazarından" ("By the author of Waverley") ibaresini kullanmıştır (1997, s. 43). Genette'e göre büyük bir "edebiyat stratejisti" olan Scott, romanlarının isimsiz yayımlanmasının merak uyandırdığını ve böylelikle başarısına katkıda bulunduğunu fark etmiş ve ismini gizlediği zaman daha iyi bir yazar olduğunu öne sürmüştür (s. 43). Genette, Scott'ın her ne kadar 1829 yılına kadar eserlerinde ismini kullanmamış olsa da aradaki süre zarfında tamamen anonim kalmadığını belirtmiştir. Bazı eleştirmenler Scott'ın şiirleri ve romanları arasındaki bağlantıları kurarak bu isimsiz eserleri Scott'ın kaleme aldığını fark etmiş; 1818 yılından itibaren romanlarının Fransızca çevirileri "Sir Walter Scott" imzasıyla yayımlanmaya başlamıştır (s. 44). Kronolojik olarak bakıldığında The Talisman'ın 1825 yılında, yani yazarın romanlarında adını kullanmaya başlamadan önce yazıldığı görülmektedir. Ancak 1934 yılına gelindiğinde romanın hâlihazırda yazarın ismi belirtilerek Osmanlıcaya çevrilmiş olduğunu ve yazarın tüm dünyada tanındığını göz önünde bulundurarak Maarif Kitaphanesi'nin 1934 baskısında yazar ismi belirtmemesinin kasıtlı bir tercih olduğunu söylemek mümkündür.

Maarif Kitaphanesi aynı metni birtakım küçük değişiklikler yaparak, farklı başlıklarla ve görsellerle birçok kez yayımlamıştır. Yukarıda belirtildiği üzere 1934 yılında yazar ismi belirtilmemiş olmasına karşın aynı metin 1942 yılında Salâhaddîni Eyyubî: Meçhul Kadın başlığıyla yayımlanmış, kitabın kapağına “ingiliz Muharriri Valter Skot'dan” notu eklenmiş, ancak çevirmen adı belirtilmemiştir. Eserin aynı başlıkla, notla ve kapak görseliyle 1953 ve 1956 yıllarında yeniden basıldığı tespit edilmiştir. 1964 yılında ise "Maarif Kitaphanesi Çocuk Kitapları" serisi altında Salâhaddini Eyyubî ve Arslan Yürekli Rişar başlığıyla yayımlanmış ve kitabın iç kapağında kaynak metnin Scott tarafından yazıldığı bilgisi verilmiştir. Kaynak metin yazarının ismi belirtilmiş olmasına karşın bu baskıda da çevirmen adı belirtilmemiştir.

Cumhuriyet Dönemi'nde İngilizce özgün metinden yapılmış olan ilk Türkçe çeviri ise Avesta Yayınevi tarafından 2015 yılında yayımlanmıştır. Burcu Yalçınkaya'nın Türkçeye çevirdiği metin Haçlı Hikayeleri: Tılsım başlığıyla yayımlanmış, iç ve dış kapaklarda başlığın altına "Arslan Yürekli Richard ve Sultan Selahaddin" ifadesi eklenmiştir. Metnin girişinde Scott’ın 1832 yılında kaleme aldığı önsöz bulunmaktadır. Başlığın çevirisinde kitabın konusu ve ana kahramanlarına dair bilgi vermek amacıyla ekleme yapıldığı görülmektedir. 
Timaş ve Ötüken'in çevirileri diliçi çeviri bağlamında ilgi çekici bir vaka olarak değerlendirilebilir. Zira The Talisman Fransızcaya Richard en Palestine ou Le Talisman başlığıyla, M. Albert Montémont tarafından çevrilmiştir. Mehmed Halid de Osmanlıca metni Fransızcadan çevirdiği için, bu iki yayınevi tarafından yayımlanan metinler "aradilden" yapılmış "dillerarası" bir çevirinin "diliçi" çevirisi olarak nitelendirilebilir. 1910 yılının koşullarında, artsüremli bir bakış açısıyla değerlendirilecek olduğunda Batı edebiyatından çoğu eserin aradilden, özellikle Fransızcadan, çevrilmesi yaygın bir pratik olduğundan Halid'in Fransızca metni esas alması olağan karşılanabilir. Ancak İngilizcenin tarihsel süreçte lingua franca statüsüne erişmiş ve Scott'ın diğer eserlerinin Türkçeye çevrilmiş olmasına karşın The Talisman 2015 yılına dek İngilizce aslından çevrilmemiştir.

\section{Kuramsal ve Yöntemsel Çerçeve}

The Talisman'ın 2015 yılına dek İngilizce aslından çevrilmemiş olması ve arada geçen süreçte dillerarası çevirinin diliçi çevirisinin okurlara sunulması çalışmaya konu olan bütüncenin "çevirinin doğrudanlığı" (Toury, 1995/2012) açısından betimleyici bir çalışmayla irdelenmesini gerekli kılmaktadır. Toury, "etkinliklere ilişkin toplumsallığın açıklanmasında anahtar bir kavram ve odak noktası" olarak nitelendirdiği normları "süreç öncesi çeviri normları" ve "çeviri süreci normları" olmak üzere iki ana başlık altında ele almıştır (s. 153-154). "Süreç öncesi çeviri normları" ise "çeviri politikası" ve "çevirinin doğrudanlığı" olmak üzere iki alt başlıkta ele alınmıştır (s. 153-154).

"Çeviri politikası" bağlamında "belirli bir zamanda belirli bir kültüre/dile çeviri yoluyla ithal edilecek metin türlerinin seçimini, hatta tek tek metinlerin seçimini" irdelemek mümkünken söz konusu seçimin "rastgele" yapılmadığı ortaya koyulduğu takdirde bir politikanın benimsendiği varsayılabilir (s.153). "Çevirinin doğrudanlığı" bağlamında ise çevirinin hangi dilden yapıldığına dair sorgulamalar yer almakta ve kaynak metnin (özgün dili yerine) farklı dillerden çevrilmesine karşı gösterilen "hoşgörü eşiği" araştırılmaktadır. Toury, sözünü ettiği "hoşgörü eşiği”ni açığa çıkarmak için aşağıdaki soruları sormuştur:

Dolaylı çeviriye izin verilmekte midir? Hangi kaynak dillerden/metin türlerinden/dönemlerinden çeviri yapılması(na) izin verilmektedir? Hangi kaynak/ara dillerden çeviri yapılması(na) izin verilmektedir/yasaklanmıştır/hoş görülmektedir/tercih edilmektedir? İzin verilen/yasaklanan, hoş görülen/tercih edilen aracı diller hangileridir? Bir çevirinin ara dilden yapıldığının belirtilmesi eğilimi/zorunluluğu var mıdır? Yoksa bu gerçek gözardı/kamufle/inkâr mı edilmektedir? Eğer aracı bir dilin varlığından söz ediliyorsa, aracı dilin hangisi olduğu da bildirilmekte midir? (2012, s. 154).

Toury'nin kavramsallaştırdığı şekliyle, çeviri normları, özellikle de "süreç öncesi normlar" başlığı altında yer alan "çevirinin doğrudanlı̆̆ı", The Talisman'ın Türkiye'deki diliçi ve dillerarası çevirilerinin tarihsel, toplumsal ve kültürel bağlam ile nasıl bir ilişki içerisinde olduğunu araştırmak açısından kilit öneme sahiptir. Bu doğrultuda, "bir metnin kitap haline gelmesini ve okurlara sunulmasını sağlayan" unsurlar olarak tanımlanan ve "çevre metin" ("peritext") ve "dış metin" (epitext) alt-kategorilerinden oluşan "yanmetin" ("paratext") (Genette, 1997) kavramından yola çıkılabilir. Böylece, 
"çevirilerin okurlara sunulma biçimini", "dolayısıyla bir toplumdaki çeviri metinlere ilişkin gelenekleri, kavramları ve beklentileri" açığa çıkarmaya yardımcı olan ve "genellikle çeviri metnin kendisinden önce okurla buluşan" yanmetinlerin (Krş. TahirGürçağlar, 2010, s. 113) incelenmesi yoluyla söz konusu normların tespit edilmesi ve anlamlandırıması sağlanabilir.

“Çevirmenin görünürlüğü, erek okur kitlesi, çevirinin amacı ve belli bir kültür ve/veya yayıncı tarafından tercih edilen çeviri kavramlarına ilişkin ipuçları içeren" (s. 113) yanmetinleri konu alan araştırmalar, "çeviri araştırmalarında kültürel ve ideolojik konulara duyulan ilginin artması" sonucu "yöntemsel olarak kaçınılmaz hale gelmiştir" (s. 113). Dahası, özellikle "çevirilerin üretimine ve alımlanmasına ilişkin örüntüleri açığa çıkarmaya yardımcı olan" "çevre metinler", "yazarlık, özgünlük ve anonimlik gibi kavramların sorunsallaştırılmasını mümkün kılar" (s. 114-115). Dolayısıyla, bu çalışmada, bütünceye konu çevirilerin yanmetinsel öğeleri olan iç ve dış kapaklar, önsözler, sunuş yazıları, açıklamalar ve dipnotlar betimlenerek analiz edilecek ve bu öğelerin incelenmesi sonucu varılan tespitlerden, çalışmaya konu olan çevirileri yönlendiren süreç öncesi normların açığa çıkarılmasında yararlanılacaktır.

\section{Vaka İncelemesi: Yanmetinler Odağında The Talisman Çevirileri}

Bu bölümde, çalışmanın bütüncesini oluşturan çeviri metinlerin yanmetinsel öğeleri dört alt başlık altında incelenecektir. Yapılan ön incelemede çevirmen ve yayınevlerinin yanmetinler aracılığıyla okurları yönlendirme ve kaynak eser ile çeviri eseri erek dizgede/erek kitle için konumlandırmaya çalıştıkları tespit edilmiştir. Genel anlamda, kaynak eserin Haçlı seferlerini, dolayısıyla Doğu ve Batı arasındaki bir tür yüzleşmeyi konu alan bir tarihsel roman olması, özellikle de Selahaddin Eyyubi'nin personasını öne çıkarması nedeniyle, çevirilerdeki yanmetinler, öncelikle, sırasıyla, "Doğu-Batı ilişkisi", "tarihsel gerçeklik", "Türklük vurgusu" başlıkları altında analiz edilecektir. İngilizce bir metin olan The Talisman'ın yaklaşık yüz yıllık bir süre boyunca neden Fransızca aradilden yapılan dillerarası çevirisinin diliçi çevirileriyle Türk okurlarına sunulduğu şeklindeki merkezi araştırma sorusu bağlamında ise bütüncedeki ilgili örnekler "çevirinin doğrudanlığı” başlığı altında ayrıca analiz edilecektir.

\subsection{Doğu-Batı İlişkisi}

Kaynak metin Doğulu/Müslüman ve Batılı/Hristiyan karakterlerin Kudüs'te karşılaşmasını ele almaktadır. Batı edebiyatının önde gelen isimlerinden olan ve tarihi roman türünü edebiyat dünyasına kazandıran bir yazarın Doğu'da geçen ve İslam tarihinin önemli figürlerinden birinin ana karakteri olduğu bir tarihsel olayı romanlaştırmasının iki taraf arasındaki gerilime/zıtlığa ilişkin birtakım noktaları ortaya koyacağı öngörülebilir. Buradan hareketle Doğu ve Batı arasındaki ilişkinin çeviri metinlerde ne şekilde temsil/tasvir edildiğine dair ipuçlarını içeren yanmetinsel öğeler irdelenecektir.

Mehmed Halid 1912 yılında yayımlanan çevirisine yazdığı “ifade-i Mütercim” başlıklı önsözünde kaynak metni, yazarı ve hikâyenin ana karakterlerinden Selahaddin 
Eyyubi'yi tanıtmıştır. Erol Kılınç’ın yayına hazırladığı 2012 tarihli diliçi çeviriden yapılan alıntıda görüldüğü üzere Halid’in önsözünde aşağıdaki ifadeler yer almaktadır:

Bu cengâver hamaset, adalet, kararlılık ve basiret, merhametlilik ve şefkat gibi yüksek niteliklerin hepsini kişiliğinde toplamıştı. Onun devrinde batılıların İslâm ülkelerinde gördükleri ümran ve medeniyet eserleri Avrupalıların medenîleşme yoluna girmelerine sebep olmuştur. Bu yüzden onun ahlâkî yüksekliğinin hayranı olan Avrupalılar, Selahaddin'in adını cesaret ile özdeşleştirerek daima saygıyla anarlar. [...] İşte Walter Scott, Selahaddin Eyyubî'nin yüce kişilik özellikleri ve ahlâkî yükseklikleriyle Richard'ın yaptığı zalimlikleri ve fıtratındaki kötülüğü karşılaştırmıştır. Böylece tarihî bilgelik açısından bir ibret dersi olsun diye bu eseri yazmıştır ki, İslâm hükümetlerinin tarihî geleneklerinin daima insanî faziletlere ve medenî güzelliklere uygun bulunduğunu ispat ettiğinden dolayı bizim için memnuniyet verici, yazarı için övgüyü gerektirici olsa gerekir. (ss. 7-9)

Halid Batılıların "medeniyeti" ve "medenileşmeyi" Doğululardan aldığını ve Selahattin'in ahlaki olarak Kral Richard'dan daha üstün olduğunu öne sürmektedir. Bu nedenle de Türk okurun Batılı bir yazarın gözünden anlatılan, Doğulu bir Müslüman komutanın "ibret verici" maceralarını okumasından memnun olduğunun altını çizmiştir.

Halid'in çevirisinin diliçi çevirisini yapan Dursun Gürlek de bir sunuş yazısı kaleme almıştır. Gürlek, sunuş yazısında Batılı yazarların “sihirli bir ülke” olarak gördüğü Doğu’yu merak ettiklerini ve bu nedenle İslâm tarihinden kişilerin hayatı ve maceraları hakkında birçok eser ürettiklerini belirtmiş ve Selahaddin'e olan ilginin sebeplerini aşağıdaki gibi açıklamıştır:

Savaş meydanlarında kahramanlık tabloları oluşturan, ahlâk ve fazilet nümunesi olarak arz-ı endâm eden, düşmanını bile tedavi edecek kadar asalet sahibi olan, İslâmın çağlar üstü mesajını yeryüzüne yaymak için çırpınan, yenilmez kralları yenen, eğilmez bilekleri eğen, Arslan Yürekli Rişar gibi gurur ve kibir heykeli bir hükümdarı dize getiren, müttefik haçlı ordularına en büyük dersi veren, İslâm birliğinin sembol ismi haline gelen, adalet dağıtan kılııından sıçrayan kıvılıımların ışığı asırları aşarak günümüze kadar gelen böyle dört başı mamur bir kahramanın hayatı elbette ki, Batılı yazarların dikkatini çekecekti. (1995, ss. 5-6)

Yukarıdaki alıntıda görüldüğü üzere, tıpkı Halid gibi Gürlek de ağırlıklı olarak Batı ve Doğu ilişkisi üzerinde durmuştur. İki lider arasındaki zıtıkları vurgulamak için birini "kibirli", diğerini ise "ahlâklı" ve "faziletli" olarak nitelendirmiştir. Sözü edilen sunuş yazısı ile Halid'in önsözünün ortak temalar etrafında şekillendiği söylenebilir. Zira her ikisinde de Doğu'nun Batı'ya kıyasla ne kadar çok olumlu tarafı olduğu ve dolayısıyla Doğu'nun pek çok açıdan Batı'dan “üstün” olduğu vurgulanmıştır. Halid'in ve Gürlek'in ifadelerinden hareketle çevirmenlerin metni Doğu'nun ve İslâm'ın üstünlüğünü okurlara sunan bir eser olarak konumlandırdığı sonucuna varmak mümkündür.

İslâm vurgusunun yanmetinsel öğelerde karşımıza çıktığı bir başka örnek ise Maarif Kitaphanesi'nin 1942 yılında okurlarına sunduğu Salâhaddini Eyyubî ve Aslan Yürekli Rişar başlıklı çeviride yer almaktadır. Sayfa aralarında Hazreti Muhammed'in Hayatı ve Kurduğu Dinin Esasları (1942, s. 17) ve Kerbelâ'nın Intikamı (1942, s. 65) gibi kitaplar yayınevi tarafından okurlara tanıtılmıştır. Sonuç olarak yayınevinin sözü edilen tarihte İslâm tarihiyle ilgili bilgileri içeren metinlerin tanıtılmaya uygun gördüğü ve hedef 
okurların bu konulara ilgi duyduğunu varsaydığı anlaşılmaktadır. Yayınevinin 1964 baskısı dışındaki çevirilerde de kitabın sonunda veya sayfa aralarında yine İslâm ile ilintili kitapların tanıtımına yer verdiği görülmektedir. 1964 baskısı ise "Istanbul Maarif Kitaphanesi Çocuk Yayınları C Serisi" başlığıyla okurlara sunulan serideki kitaplardan biridir. Seride Grisella (Konuşan Eşek) (Maria Dennenborg), Martılı Kaya (Jules Sandeau), Afrika Vahşileri Arasında (Vedi Vecdet), Kara Ok (Robert Stevenson) Sâlâhaddin Eyyubi (Walter Scott), Nasreddin Hoca (Toplama), Huck Finn'in Maceraları (Mark Twain), Kötü Cin (Comtesse de Ségur), Kaptan Surcouf'un Tayfası (Louis Garneray) olmak üzere toplam dokuz çeviri ve telif eserin okurlara sunulduğu görülmektedir. İslâm'la ilintili kitap tanıtımlarının 1964 baskısında olmamasının sebebini hedef okur kitlesinin farklı olmasıyla açıklamak mümkündür.

Maarif Kitaphanesi'nin yayımladığı tüm çevirilerde "Salâhaddini Eyyubî" başlıklı, kaynak metinde bulunmayan üç sayfalık bir bölüm eklendiği görülmektedir. Bu üç sayfada Salahaddin'in farklı kişilerle yaşadığı olaylara kısaca yer verilmiş ve bu olaylar üzerinden kendisinin "adil", "nazik", "namuslu", "faziletli", "dünya malına önem vermeyen", "din, milliyet farkı gözetmeden, herkes hakkında aynı muameleyi yapan" bir lider olduğu öne sürülmüştür (1964, s. 181-183). Önsöz veya sunuş yazısı olmayan bu çevirilerde kitabın sonuna eklenen bu bölüm aracılığıyla Selahaddin'in "olumlu" özelliklerinin ve İslâm tarihinde neden bu kadar önemli bir isim olduğunun vurgulandığı ve de kaynak metinde var olmamasına karşın ek bilgi içeren bu bölümün de bir yanmetin olarak değerlendirilebileceğini söylemek mümkündür.

Halid'in çevirisinde Doğu ve Batı arasındaki gerilimin izlerine ve dolayısıyla çevirmenin Kral Richard'la ilgili eleştirilerine diğer yanmetinlerde de rastlamak mümkündür. Halid, Kral Richard'ın aslana benzetilmesiyle ilgili tespitlerini aşağıdaki dipnotta okurlara bildirmiştir:

Mütercim der ki bu kral (Arslan Yürekli Rişar) lakabıyla mülakkab olmasına rağmen kendisinin arslandan ziyade her hali yırtıcı bir kaplana benzediğinden muharrir-i eser Valter İskot burada Rişar'ı arslana değil o yırtıcı hayvana teşbih etmeli idi. O zaman isim ile müsemma arasında pek hoş bir sanat-ı tezad hâsıl olur idi. (1912, s. 89)

Bu dipnot, Kılınç tarafından günümüz Türkçesine aşağıdaki gibi aktarılmıştır:

17 Mütercim der ki: Bu kral "Arslan Yürekli Richard" lakabıyla adlandırılmasına rağmen, kendisinin arslandan çok her hali yırtıcı bir kaplana benzediğinden, kitabın yazarı Walter Scott burada Richard'ı arslana değil, o yırtıcı hayvana benzetmeliydi. O zaman isim ile isim verilen arasında pek hoş bir tezat sanatı yapılmış olurdu. (2020, s. 70)

Bu dipnottan anlaşıldığı üzere Halid "aslan” benzetmesinden rahatsız olmakta ve Richard'a "yırtıcı bir hayvan" olarak nitelendirdiği "kaplan" lakabını uygun görmektedir. Selahaddin'in aksine, "zalim" ve "kötü huylu" olarak tanımlanan Richard'ın "aslan" lakabıyla anılması da çevirmen tarafından uygun görülmemektedir. Dolayısıyla, dipnot aracılığıyla metne müdahale edip kişilik özellikleri bakımından iki lider arasındaki zıtlığı vurguladığı söylenebilir. 


\subsection{Tarihsel Gerçeklik}

Tarihsel roman türü bağlamında, özellikle de bu türün kurucu babası Scott'ın romanları özelinde, "tarihsel gerçekçilik" konusu en çok tartışılan sorunsallardan biri olarak karşımıza çıkmaktadır. Bu nedenle çevirmenlerin yanmetinler aracılığıyla metinde anlatılan olayların "gerçekliği" ile ilintili herhangi bir müdahalede bulunup bulunmadığı veya Scott'ın anlatııının "gerçeklik" ile ne kadar örtüştüğüne dair görüş sunup sunmadıkları incelenmiştir.

Halid'in çevirmen önsözünde romanda tasvir edilen olay ve kişilerin "gerçekliği"ne dair tespitleri Kılınç'ın 2012 tarihli diliçi çevirisinde aşağıdaki gibi aktarılmıştır:

Söze son vermeden evvel şurasını da arz edelim ki, Walter Scott tarihî hakikatleri asla bozmaksızın hikâyesinin zeminine itibarî (kurgusal), hayalî bazı detaylar eklemiş veya gerçek kişilere bazı roller vermiştir ki, bir roman yazarının hak ve yetkisi çerçevesinde olan bi kabil sanatkârane kurgulamaların hikâye zemînini bir derece daha süsleyeceği ve okuyucuların merakını bir kat daha çekeceği şüphesizdir. (ss. 8-9)

Önsözde yer alan bu bilgilerden yola çıkarak Halid'in yazarın müdahalelerini bir anlamda "gerekli" gördüğü söylenebilir. Çevirmen, yazarın hikâyeye ekleme yapmaya yetkisi olduğunu öne sürmüş ve bu yetkiyi esere ve dolayısıyla okura hizmet etme gerekçesiyle yazara vermiştir. Halid'in (her ne kadar yazarın müdahalelerine hoşgörülü yaklaşmış olsa da) gerekli gördüğü yerde dipnot ekleyerek "gerçekte" ne olduğunu okurlara aktarma ihtiyacı hissettiği de aşă̆ıdaki örnekte görülmektedir:

Üçüncü Sefer esnasında Antakya (Karasu) nehrini geçer iken boğulmuş olan Almanya imparatoru (Frederik Barbaros)un oğlu diye kaydedilmiş ise de doğru değildir. Garikan vefat eden Frederik'in oğlu ve halefi (Hanri lö Kruel) olup (Leopol) bunun akrabasından idi. Almanya hanedan-ı hükümdarisi tarafından kendisine (dük) unvanı verilmiş ve (Tuna) nehrinin iska ettiği en güzel eyaletlerin idaresini de (Leopol) deruhte eylemiş idi. (1912, s. 177)

Halid'in kaynak metnin "tarihsel gerçekliği"nden emin olduğu ve müdahale hakkını Scott'a verdiğini önsözde belirtmiş olmasına karşın bu dipnotu ekleyerek düzeltme yapması çelişkili bir tavır olarak görülebilir. Kılınç ise sözü edilen dipnotu diliçi çeviride aşağıdaki gibi aktarmıştır:

Bazı tarih kitaplarımızda bu Arşidük Leopold Üçüncü Haçlı seferi esnasında Antakya Göksu (Mersin, Göksu ırmağı olacaktır. E.K.) nehrini geçerken boğulmuş olan Almanya imparatoru Friedrich Barbarossa'un oğlu diye kaydedilmişse de doğru değildir. Boğularak ölen Friedrich'in oğlu ve halefi Heinrich olup Leopold bunun akrabasındandı. Almanya hükümdarlık hanedanı tarafından kendisine "Dük" ünvanı verilmiş ve Tuna Nehri'nin suladığı en güzel eyaletlerin idaresini de Leopold üzerine almıştı. (M.H.) (2012, s. 174)

Kılınç'ın dipnota parantez içinde söz konusu ırmağın Antakya'daki Karasu yerine Mersin'deki Göksu Irmağı olduğu bilgisini eklemiştir. Dolayısıyla Kılınç'ın da benzer bir anlayışla Halid'in dipnotuna müdahale ederek "hata"sını düzelttiği gözlemlenmektedir. Gürlek'in ise Halid'in dipnotuna diliçi çeviride yer vermemiştir. 
Metinde kum saatinin kullanıldığı kısma bir dipnot ekleyen Halid aşağıdaki bilgiyi okurlara aktarmıştır:

Bu sözden istidlâl olunur ki ehl-i sâlib vukuatı zamanına tesadüf eden bin yüz şu kadar tarih-i miladisinde Avrupalılar "kum saati" ile tayin-i evkat ederler imiş. Halbuki Bağdat halifesi Harun el-Reşid sekiz yüz tarih-i miladisinde yani vakayi-i salibiyeden üç yüz şu kadar sene evvel garb imparatoru Şarlman'a mükemmel ve çarh ile işler bir saat ihda ve irsal eylemiş idi. (1912, s. 225)

Gürlek'in diliçi çevirisinde ilgili dipnot günümüz Türkçesine aşağıdaki gibi aktarılmıştır:

Bu sözden anlaşıldığına göre, Haçlı savaşlarının devam ettiği yıllarda Avrupalılar "Kum Saati" kullanmaktadırlar. Halbuki Harun Reşid Haçlı seferlerinden üçyüz sene önce İmparator Şarıman'a bir çalar saat göndermişti. (1995, s. 159)

Bu dipnotta, özgün metinde adı geçmemesine karşın, tıpkı Selahaddin gibi İslâm tarihinin önde gelen isimlerinden biri olan Abbasi Halifesi Harun Reşid'e atıf yapıldığı görülmektedir. Hikâyenin Haçlı seferlerinin yapıldığı zaman diliminde yer aldığını göz önünde bulundurarak karakterlerin kum saati kullanmasını yadırgayan Halid'in hem bu "hatayı" düzeltmek hem de önsözünde vurguladığı “medeniyet"i Batı'nın Doğu'dan aldığına dair bir "kanıt" olarak bu bilgiyi eklediği sonucuna varmak mümkündür.

Maarif Kitaphanesi Selahaddin'in Kral Richard'a hitaben yazdığı mektuba metinde yer vermiş ve aşağıdaki dipnotu eklemiştir:

Bu mektup meşhur İngiliz muharriri Valter Sikot'un (Sâlahaddini Eyyubî ve Aslan yürekli Rişar) adlı kitabının tercümesinin 123 üncü sahifesinde aynen yazılıdır. (1934, s. 50)

Önceden belirtildiği üzere Maarif Kitaphanesi 1934 basımında kaynak metnin adını, kaynak metnin yazarını veya çevirmeni belirtmemiştir. Scott'ın ve kaynak metnin isminin yalnızca yukarıdaki dipnotta belirtildiği tespit edilmiştir. Her ne kadar sonraki basımlarda Scott'ın ismi eklenmiş olsa da bu dipnotun korunduğu görülmektedir. Bu örnekte dikkat çekici olan doğrudan Halid'in çevirisindeki mektuba atıf yapılmış olmasıdır. Benzer bir şekilde, Türkçe çevirinin kaynak olarak belirtildiği bir dipnot daha eklendiği görülmektedir:

[1] Bu sözler, ingiliz muharriri Valter Skotun kitabının tercümesinden aynen alınmıştır. $(1934$, s. 56)

Yukarıdaki dipnot Selahaddin Eyyubi ve Başpiskopos arasında geçen konuşmaya eklenmiştir. Hastanın yanında yüksek sesle konuştuğu için Başpiskopos'u uyaran Selahaddin, köpeğin bile çadırın uzak bir köşesinde, kısık sesle havladığına dikkat çeker. Hastayı rahatsız etmemek için Başpiskopos'u çadırın dışına davet eder. Okurların bazı olayların "gerçekliği” konusunda şüpheye düşeceğinin öngörüldüğü noktada dipnotlar eklenerek başka bir çeviriye ve Scott'a atıf yapıldığını, böylelikle Maarif Kitaphanesi'nin yayımladığı metni bir nebze korumaya aldığını öne sürmek mümkündür. Kaynak metni kaleme alan ve "gerçekleri" okurlara sunan aslında Scott'tır. Dolayısyla, Scott'ın metnine tarihsel gerçekleri anlatan bir "kaynak metin" statüsünün atfedildiği ve başka bir çeviri üzerinden "tarihsel gerçekliğin" okurlara aktarıldığı söylenebilir. 


\subsection{Türklük Vurgusu}

Metin incelemesi sonucunda Maarif Kitaphanesi'nin yayımladığı metinlerde en çok öne çıkan noktalardan biri "Türklük" vurgusuna metnin yanmetinsel öğelerinde sıkça yer verilmesidir. Bu duruma ilişkin ilk örnek Maarif Kitaphanesi’nden 1934 yılında çıkan ilk çeviride görülmektedir. Söz konusu kitap formalar halinde yayımlanmıştır. Her formanın kapağındaki görselin açıklaması, metnin ilk sayfasında dipnot olarak açıklanmıştır. Örneğin ikinci formanın ilk sayfasında sayfanın sonuna "dikkat" başlığıyla bir not düşülerek, birinci formanın kapağındaki görselin "Türk ve Müslüman cengâverlerin kullandıkları silâhlar", ikinci formanın kapağındaki görsellerin ise "Avrupa şövalyelerinin kullandığı silâhlar" olduğu belirtilmiştir (1934: 17). Yine aynı çeviri metinde formalardan bazılarının sonunda yer alan kitap tanıtımında eser "Büyük Türk kahramanı Selâhaddini Eyyubî” başlığıyla okurlara sunulmuştur (Bkz. Ek 2). Eserde Selahaddin Eyyubi'nin tek başına bütün Avrupa Kral ordularını nasıl yendiğinin ve başından geçen maceraların anlatıldığı okurlara bildirilmiştir. Dolayısıyla yayınevinin yanmetinsel öğeler olan görsellerle "Türklük" vurgusunu yaptığı söylenebilir.

Yayınevinin bu bağlamdaki müdahaleleri kapak görselleri ve görsellerin açıklamalarıyla sınırlı değildir. Farklı yıllarda yayımlanan metinlere aşağıdaki dipnotları ekledikleri tespit edilmiştir:

[1] Ata bey: Öz Türkçe bir kelimedir. Türkler, büyük kabile reislerine (Ata bey) unvanını verirlerdi.

Ata: Türkçe baba demektir. Hâlâ Azerî Türkleri babaya ata demektedirler. Atabey: Beybaba demektir.

[2] Salâhaddini Eyyubî: Aral [*] Türklerinden Eyyub beyin oğlu, Yusuf beyin lakabıdır. Yusuf beyin kurduğu hükümete (Eyyub hükümeti) denmiştirki, babası Eyyub beyin adıdır.

[*] Aral: Azerbaycanda yerin adıdır. Aral türkleri orada yaşarlardı. ${ }^{2}$ (1934, s. 14)

(1) Halife: Eskiden, Peygamberin vekili ve bütün Müslümanların koruyucusu olan İslâmların reisi.

(2) Atabey: Öztürkçe bir kelimedir. Türkler büyük kabile reislerine (Atabey) unvanını verirlerdi. Ata, Türkçe baba demektir.

(3) Salâhaddini Eyyubi, Azerbaycan'ın Ural Türklerinden Eyyub beyin oğlu, Yusuf beyin lâkabıdır. Yusuf beyin kurduğu hükümete (Eyyubî) hükümeti denmiştir. (1964, s. 15)

1934 baskısındaki 2 numaralı dipnotta Aral bölgesinden bahsedilmiş, Aral'ın açıklaması ise dipnotun altına bir dipnot daha eklenerek verilmiştir. 1964 baskısındaki dipnotta ise sözcük düzeyinde birtakım değişiklikler yapıldığı ve "Aral" dipnotunun çıkarıldığı görülmektedir. Her iki baskıda da çeviri metinde Öz Türkçe sözcüklerin tercih edilmesi ve hem sözcük seçimine hem de tarihsel arka planına dair açıklamalara yer verilmesi dikkat çekicidir. 1934 baskısının 2, 1964 baskısının 3 numaralı dipnotunda Selahaddin'in Ural Türkleri'nin soyundan geldiği iddiası okurlara sunulmuştur. Buradan hareketle, yayınevinin Selahaddin'i bir "Türk kahramanı" olarak konumlandırdığı sonucuna varmak mümkündür.

${ }^{2}$ Çevirmenin yazım ve noktalama işaretleri ve vurguları aynen korunmuştur. 
Maarif Kitaphanesi'nin yayımladığı çevirilerde dikkati çeken bir başka nokta da yayınevinin Öz Türkçe kullanımına ilişkin hassasiyetidir. Örneğin "yerlığ" ve "nuyan" sözcükleri tercih edilmiş ve anlamları dipnotlarla verilmiştir:

[1] Yerlığ: Tam Türkçe kelimedir, ferman demektir.

[2] Nuyan: Tam Türkçe kelimedir, onbinler kumandanı demektir. (1934, s. 163)

Yukarıdaki sözcüklerin yayınevinin 1942 ve 1964 baskılarında da yer aldığı ve dipnotların korunduğu tespit edilmiştir. Tarihsel açıdan bakılacak olduğunda 1928 yılında Harf Devrimi'nin gerçekleştirilmesi ve ilerleyen yıllarda Türkçenin Arapça ve Farsça kökenli sözcüklerden arındırılarak Öz Türkçe sözcüklerin tercih edilmesi yaygın bir pratik olarak karşımıza çıkacaktır. Hatta Türk Dil Kurumu tarafından 1932, 1934 ve 1936 yıllarında gerçekleştirilen Türk Dili kurultaylarında dilin yabancı sözcüklerden arındırılması gündem maddelerinden olduğu için bu pratiğin bir devlet politikası olduğu ve yayınevinin bu politika doğrultusunda hareket ettiğini öne sürmek mümkündür (Krş. Lewis 1999/2007, s. 63-67).

Halid'in 1912 tarihli çevirisinin diliçi çevirileri Türklük vurgusu bağlamında incelendiğinde, okurlara Türk tarihiyle ilgili bilgilerin verildiği bir dipnot tespit edilmiştir. Sözü edilen dipnot, Kılınç tarafından günümüz Türkçesine aşağıdaki gibi aktarılmıştır:

${ }^{14}$ Şam (Suriye) Selçuklularından Tâcü'd-devle'nin oğlu Melik Rıdvan zamanında Birinci Haçlı hücumlarına karşı cihat eden Türk gazilerinin evlad ve torunlarıyla, daha sonraları İznik önlerinde bu aç ve sefil güruhun çoğunu kılıçtan geçirmiş olan yine Selçuklulardan ikinci Kılıç Arslan'ın yiğit gazilerinin Suriye taraflarında kalanlarıdır. (2020, s. 43-44)

Engedili Theodorick isimli karakterin Araplar ve Türkler tarafından korunduğunu açıklayan cümleye Halid tarafından eklenen dipnotta okurlara tarihsel arkaplan bilgisi sunulmaktadır. Tarihimizde önemli bir yeri olan Selçuklu Hanedanlığının da Birinci Haçlı Seferi'nde savaştığı ve geniş bir coğrafyada varlık gösterdiği vurgulanmıştır.

\section{Çevirinin Doğrudanlığı}

Uzunca bir süre boyunca farklı yayınevleri tarafından diliçi çevirileri okurlara sunulan ve bu çalışmada Türkçedeki ilk The Talisman çevirisi olarak kabul edilen Halid'in 1912 tarihli çevirisinin aradilden yapılıp yapılmadığına ilişkin bir inceleme yapılmış ve çevirinin doğrudanlığına ilişkin yanmetinsel öğeler tespit edilmiştir. Çevirinin doğrudanlığı bağlamındaki örnek Halid'in aşağıdaki dipnotudur:

(Richard Cœur-de-Lion) olduğuna bakarak bazı zevat harfiyen tercüme gayretiyle (Arslan Yürek Rişar), bazıları da (Arslan Yüreği Rişar) diye tercüme etmişler ise de tercüme selikamıza muvafık olmadığı gibi aslına da mutabık değildir. Çünkü aslında (au) edat-ı nisbeti mukadderdir. Yani aslı (Richard au Cœur-de-Lion) takdirindedir ki (Arslan Yürekli Rişar) demek olduğu derkârdır. Fransız lisanında böyle Elliptique tabirler nadir değildir. (1912, s. 83)

Halid'in Kral Richard'ın Fransızcada yaygın olarak kullanılan lakabı "Richard Cœurde-Lion"u kaynak olarak göstermesi, Fransız dilinde nasıl kullanıldığına dair tespitlerini sunması metnin Fransızcadan çevrildiğine dair bir göstergedir. 
Halid'in çevirisinde Fransızca kullanımına ilişkin başka örnekler de mevcuttur. Örneğin, kaynak metinde "the sick-chamber of the patient is the kingdom of the physician" ["hastanın odası doktorun krallığıdır"] (Scott 1825, s. 83) olarak geçen ve "hastanın odası hekimin ülkesidir" şeklinde Osmanlı Türkçesine çevrilen atasözünün çevirmen dipnotunda açıklandığı görülmektedir:

Mütercim der ki: Lisanımızda böyle bir darb-ı mesel olduğunu bu aciz tahattur edemiyor. Lakin mutlaka Arapçası vardır. Olmasa idi Valter İskot böyle güzel bir sözü İslâm’a bedava mâl etmez idi. Fakirin tercümesi muharririn: La chambre du malade est le royaume du médecin diye derç etmiş olduğu cümlenin naklinden ibarettir. (1912, s. 115)

Mütercim der ki: Dilimizde böyle bir darbımesel olduğunu bu aciz hatırlamıyor. Lakin mutlaka Arapçası vardır. Olmasaydı Walter Scott böyle güzel bir sözü İslam’a bedavaya mal etmezdi. Fakirin tercümesi yazarın "La chambre du malade est le royaume du médecin" diye yazmış olduğu cümlenin aktarılmasından ibarettir. (2012, s. 115)

Dilimizde böyle bir darb-ı mesel olduğunu şahsen ben hatırlamıyorum. Belli ki Arapçası varmış. Olmasaydı, Walter Scott böyle güzel bir sözü İslama boş yere mal etmezdi. MÜTERCIM. (1995, s. 75)

Fransızca çeviriyle bir karşılaştırma yapıldığında sözü edilen atasözünün Fransızcaya "la chambre du malade est le royaume du médecin" (Scott (çev. Montémont), 1837: 92) şeklinde çevrildiği ve Halid'in bu atasözünü dipnotunda birebir kullandığı görülmektedir. Bu örnekler ışığında, Türkçeye yapılan ilk çevirinin Fransızcadan, yani ara dilden yapıldığı anlaşılmaktadır. Fransızcanın söz konusu dönemin lingua francası olması ve Batılı yazarların eserlerinin Fransızcadan çevrilmesinin yaygın bir uygulama olduğu düşünüldüğünde Halid'in dönemin normlarına uygun olarak aradilden çeviri yaptığı söylenebilir.

Maarif Kitaphanesi'nin yayımladığı çevirilerde ise dipnotlarda Fransızca sözcükler, atasözleri deyimler vb. kullanılmadığı görülmüştür. Ancak 1964 baskısına romanda geçen yabancı isimlerin Fransızca Yazılışları ve Türkçe okunuşlarının eklendiği tespit edilmiştir (Bkz. Ek 7). Bu da Maarif Kitaphanesi'nin yayımladığı metinlerin Fransızcadan çevrildiğine veya Fransızcadan yapılmış Türkçe bir çevirinin diliçi çevirisi olduğuna dair bir başka kanıt olarak değerlendirilebilir.

\section{Tartışma}

Dünya edebiyat tarihinde, tarihsel romanın kurucu figürü olarak karşımıza çıkan Walter Scott'ın İngilizce kaleme aldığı The Talisman romanının 1912 yılında Fransızcadan Osmanlıcaya yapılan dillerarası çevirisinin diliçi çevirileri, yaklaşık yüz yıllık bir süreç boyunca Türk okurlara sunulmaya devam etmiş, dolayısıyla çeviribilim açısından incelemeye değer bir vaka haline gelmiştir ${ }^{3}$.

The Talisman bir İslâm ordusu komutanıyla Hristiyan bir kralın Doğu coğrafyasında karşılaşmasını ve Batı́nın Doğu'ya bakış açısını tarihsel bir olaydan yola çıkarak kurgusal bir formatta sunmaktadır. Eserin içeriğinin söz konusu özelliği nedeniyle, tarihsel roman türündeki bu eserin çevirilerindeki yanmetinlerde, Doğu-Batı

${ }^{3}$ Tarihsel roman çevirisini çeviribilim odağıyla ele alan bir çalışma için bkz. Avşaroğlu 2021. 
ilişkisinin/geriliminin yansımalarının izinin sürülüp sürülemeyeceği ve tarihsel roman çevirisi ve tarihsel gerçeklik bağlamında çevirmen-yazar ilişkinin dinamikleri ile "kurgu" "gerçeklik" ikili karşıtlığının söz konusu vakada nasıl işlediği sorularına cevaplar aranmıştır.

Çalışmanın betimleyici analiz bölümünde, çalışmanın bütüncesini oluşturan çevirilerin yanmetinsel öğeleri, "Doğu-Batı ilişkisi", "tarihsel gerçeklik", "Türklük vurgusu" ve "çevirinin doğrudanlı̆̆ı" başlıkları altında incelenmiştir. Çalışma kapsamında yürütülen betimleyici incelemenin sonucunda, yanmetinsel öğelerde Doğu ve Batı arasındaki gerilimin güçlü izdüşümlerine rastlanılmıştır. Yanmetinlerdeki, genel kanının aksine, "medeniyet"in Batıdan Doğuya değil, Doğudan Batıya alındığına yönelik ifadelerin, Osmanlı döneminde yapılan dillerarası çeviride ve dolayısıyla bu çevirinin diliçi çevirilerinde özellikle ön plana çıktığı saptanmıştır. Yanmetinlerde, "kötü" ve "zalim" bir lider olarak nitelendirilen Kral Richard'a Selahaddin'in gösterdiği "merhametin" ve hikâye boyunca "ibret verici" olarak tanımlanan tüm kişilik özelliklerinin tarihsel süreçte, farklı yayınevlerinin yayımladığı çevirilerin yanmetinlerinde İslâm diniyle veya Türklükle koşutluk kurularak anlatıldığı söylenebilir.

Maarif Kitaphanesi'nin çevirileri ile Mehmed Halid'in çevirisindeki vurgu noktalarının iki farklı eksende seyrettiği belirlenmiştir: ilki Selahaddin'i bir "Türk komutanı" olarak konumlandırırken ikincisi "İslâm birliğinin sembol ismi" olarak konumlandırmıştır. Osmanlı döneminde Fransızcadan Osmanlıcaya yapılan dillerarası çeviride, İslâm ümmetini yeniden bir araya getirme/diriltme amacıyla koşut bir söylemin benimsendiği ve bu söylemin 1990'lı yılların sonlarında yayımlanmaya başlanan ve 2020 yılında hala yeniden yayımlanmaya devam edilen diliçi çeviriler yoluyla yeniden üretildiği söylenebilir. Ancak Cumhuriyet döneminde Maarif Kitaphanesi'nin, devlet politikalarıyla koşut olarak, Öz Türkçe kullanımı konusunda hassasiyet gösterdiğini, Türk dünyasıyla ilgili çeşitli alanlarda (tarih, dil, kültür vb.) yürütülen çalışmaların ve kökenlere geri dönüş çabasının da bir sonucu olarak Türklük konusunu vurguladığını varsaymak mümkündür. Bu doğrultuda, Osmanlı ve Cumhuriyet dönemlerinde yayımlanan ve sözü edilen metinlerde ortak tema olarak "İslâm" ve "Türklük"ün karşımıza çıktığı, her ikisinin de genel anlamda "Doğu" çatısı altında ele alınabileceği ve yanmetinlerde, Haçlı Seferleri sırasında Doğu'dan Batı'ya bir "medeniyet" aktarımı yapıldığına dair yönlendirmelerin bulunduğu söylenebilir.

\section{Sonuç}

Kaynak eser roman türünde olmasına karşın, Scott'ın aslında gerçek olaylardan mümkün olduğunca sapmadığının ve uzman bir edebiyatçı olduğunun belirtildiği, hatta kaynak metnin geçmişte gerçekten yazılmış bir mektubu yayımlayan bir "tarih kitabı" olarak konumlandırıldığı görülmüştür. İlgili literatürde, tarihsel romanın gerçekleri "olduğu gibi", "çarpıtmadan", "eksiksiz" bir şekilde okurlara sunmasının bu türün doğası gereği mümkün olmadığı vurgulanmıştır. Dolayısıyla, yazarların kurguyu inşa edebilmesi için tarihsel olaylarda birtakım değişiklikler yapması hoşgörüyle karşılanmaktadır. Ancak The Talisman romanının bu çalışma kapsamında incelenen çevirilerinde sözü edilen görüşün 
aksi bir durumun geçerli olduğunu söylemek mümkündür. Çevirmenler yanmetinlerde "tarihsel gerçeklik" konusunda hassasiyet gösterdiklerini ve gerektiğinde düzeltmeler ve ek bilgilerle okurlara "gerçekleri" aktarmak istediklerini göstermişlerdir. Bunun sonucu olarak da hem çevirmenlerin yanmetin kullanımı aracılığıyla görünür hale geldikleri, hem de tarihsel roman çevirisi bağlamında hem "çevirmen" ve "yazar" hem de "kurgu" ve "gerçeklik" arasındaki sınırların bulanıklaştığı söylenebilir.

Yanmetinsel öğelerin kullanım işlevleri ile ilgili söz konusu tespitler, çalışmanın merkezi araştırma sorusu ile ilişkilendirildiğinde, bütüncedeki çevirilerin üretiminde yer alan ve yanmetin kullanımıyla görünür hale gelen eyleyenlerin dillerarası çeviriye neden gereksinim duymadıkları sorusunun cevabı, eyleyenlerin çeviri metne yükledikleri işlevde yattığını söylemek mümkündür. İnceleme sonucunda metnin ilk olarak 1910 tarihinde, aradilden çevrildiği tespit edilmiştir. Dönemin çeviri politikaları göz önünde bulundurulduğunda, Fransızca aradilden çeviri yapılması yaygın bir pratik olmakla beraber, Cumhuriyet döneminde yayımlanan metinlerin diliçi çeviriler olması ve 2015 yılına dek İngilizce kaynak metinden yapılmış bir çevirinin yayımlanmaması, Halid’in çevirisinin yayımlandığı dönemde üstlenmiş olduğu işlevin geçerliliğini koruduğuna yönelik bir olasılığa işaret edebilir. The Talisman'ın Türkiye'deki bir asırlık çeviri macerası boyunca, dillerarası çeviriye gerek duyulmamasının nedeni, yanmetinlerle şekillendirilerek/konumlandırılarak erek-dizgede işlevsel bir metnin üretilmiş ve sürekli yeniden-üretiliyor olmasıdır denilebilir.

Söz konusu yeniden üretim sürecindeki eyleyenler olan diliçi çevirmenlerin uzman kimliklerine değinmek gerekmektedir. Gerek edebiyat ve tarih gerekse diliçi çeviri alanında uzman olan Dursun Gürlek ve Erol Kılınç'ın çeviri süreçlerinin eyleyenlerinden olmaları da burada önemli bir etken olarak karşımıza çıkmaktadır. Gürlek ve Kılınç, birçok metni Osmanlıcadan diliçi çeviri aracılığıyla aktararak günümüz okurlarıyla buluşturmuşlardır. Dolayısıyla, var olan örneklerin erek okur kitlesi tarafından onandığı ve çevirmenlerin uzman kimliklerine güven duyulduğu durumlarda kaynak dilden çevrilmesi ihtiyacının ortadan kalkmış olduğu ileri sürülebilir.

Sonuç olarak, bu çalışmanın, tarihsel roman çevirisi bağlamında, çevirinin doğrudanlığına ilişkin normlar ile erek-dizgedeki eyleyiciler tarafından çeviri metne yüklenen işlev arasındaki ilişkiyi örneklendirdiği iddia edilebilir. Söz konusu ilişkinin farklı metin türleri, farklı zaman dilimleri ve farklı diller ve kültürleri de kapsayacak şekilde genişletilmesi, tarihsel çeviribilim araştırmalarını daha da derinleştirebilir.

\section{Kaynakça}

12 inci asırda Salip Muharebeleri: Salâhaddini Eyyubi ve Arslan Yürekli Rişar. (1934). Maarif Kitaphanesi.

12 inci asırda Salip Muharebeleri: Salâhaddini Eyyubi ve Arslan Yürekli Rişar. (1949). Maarif Kitaphanesi.

Alexander, J. H. (2017). Walter Scott's Books: Reading the Waverley Novels. Taylor \& Francis.

Avşaroğlu, M. (2021). Tarihsel Roman ve Çeviri: Jason Goodwin'in Çeviri Romanları Üzerine Betimleyici Bir Çalışma [Yayımlanmamış doktora tezi]. Yıldız Teknik Üniversitesi. 
Berk Albachten, Ö. (2013). Intralingual translation as 'modernization' of the language: the Turkish case. Perspectives, 21(2), 257-271. https://doi.org/10.1080/0907676X.2012.702395

Brown, D. (2016). Walter Scott and the historical imagination [Adobe Digital Editions]. Routledge. https://doi.org/10.4324/9781315625942 (Özgün metin 1979 yılında yayımlanmıştır)

Çelik, Y. (2002). Tarih roman ilişkisi-tarihi romanda kişiler. Bilig, 22 (Yaz), 49-68.

Genette, G. (1997). Paratexts: Thresholds of interpretation. Cambridge University Press.

Göğebakan, T. (2004). Tarihsel Roman Üzerine. Akçağ Yayınları.

Jakobson, R. (2012). Çevirinin Dil(bilim)sel Özellikleri Üstüne. (Ö. Albayrak, Çev.) Çeviri Seçkisi II (2. Bs.). İstanbul: Sel Yayıncılık: 61-66. (Özgün metin 1959 yılında yayımlanmıştır)

Kalem Bakkal, A. (2019). From the 'real' author to the 'real' reader: Manipulation in translation. transLogos Translation Studies Journal, 2(1), 85-101. http://dx.doi.org/10.29228/transLogos.2/1.5

Kara, H., \& Aravi, M. (2017). Osmanlı'yı tahayyül etmek: tarihsel romanda Fatih temsilleri. Boğaziçi Üniversitesi Yayınevi.

Karadağ, A. B. (2012). Bir diliçi çeviri örneği olarak dipnotlar ve dipnotlarla bir çeviriyi yeniden yazmak. Çeviribilim Dergisi, 8, 35-40.

Kemal, N. (1305/1889). Mukaddeme-i Celâl. Ebüzziya Matbaası.

Korning Zethsen, K. (2007). Beyond translation proper-Extending the field of translation studies. TTR: traduction, terminologie, rédaction, 20(1), 281-308. https://doi.org/10.7202/018506ar

Korning Zethsen, K. (2009). Intralingual translation: An attempt at description. Meta: journal des traducteurs, 54(4), 795-812. https://doi.org/10.7202/038904ar

Lewis, G. (2007). Trajik Başarı: Türk Dili Reformu (M. F. Uslu, Çev.) Paradigma Yayınları. (Özgün metin 1999 yılında yayımlanmıştır)

Lincoln, A. (2007). Walter Scott and Modernity. Edinburgh University Press.

Lukács, G. (2010). Tarihsel Roman (i. Doğan, Çev.) Epos Yayınları. (Özgün metin 1962 yılında yayımlanmıştır)

Mardin, Ş. (1996) Yeni Osmanlı Düşüncesinin Doğuşu (M. Türköne, F. Unan, İ. Erdoğan, Çev.). İletişim. (Özgün metin 1962 yılında yayımlanmıştır)

Mayer, R. (2017). Walter Scott and Fame: Authors and Readers in the Romantic Age. Oxford University Press.

Said, E. (2017) Şarkiyatçııı: Batı’nın Şark Anlayışları (B. Yıldırım, Çev.) (10. Bs.). Metis Yayınları. (Özgün metin 1978 yılında yayımlanmıştır)

Salâhaddini Eyyubî ve Arslan Yürekli Rişar. (1964) Maarif Kitaphanesi.

Salâhaddîni Eyyubî: Meçhul Kadın. (1942). Maarif Kitaphanesi.

Salâhaddîni Eyyubî: Meçhul Kadın. (1953). Maarif Kitaphanesi.

Salâhaddîni Eyyubî: Meçhul Kadın. (1956). Maarif Kitaphanesi. 
Scott, W. (1825) The Talisman. J \& J Harper Printers.

Scott, W. (1837) Richard en Palestine ou Le Talisman (M. A. Montémont, Çev.). (Özgün metin 1825 yılında yayımlanmıştır)

Scott, W. (1912) Selahaddin-i Eyyubî ve Arslan Yürekli Rişar: Ehl-i Salib Vukuatına Müstenid Tarihî Roman (M. Halid, Çev.). Mihran Matbaası.

Scott, W. (1995) Selahaddîn-i Eyyûbî ve Arslan Yürekli Rişar (D. Gürlek, Sad.). Timaş. (Özgün metin 1912 yılında yayımlanmıştır)

Scott, W. (2012) Selahaddin Eyyubî ve Arslan Yürekli Richard (3. Haçlı Seferinin Filistin Safhasının Romanı) (1. Bs.) (E. Kılınç, Yay. haz.). Ötüken. (Özgün metin 1912 yılında yayımlanmıştır)

Scott, W. (2013) Selahaddin Eyyubî ve Arslan Yürekli Richard (3. Haçlı Seferinin Filistin Safhasının Romanı) (2. Bs.) (E. Kılınç, Yay. haz.). Ötüken. (Özgün metin 1912 yılında yayımlanmıştır)

Scott, W. (2020) Selahaddin Eyyubî ve Arslan Yürekli Richard (3. Haçlı Seferinin Filistin Safhasının Romanı) (3. Bs.) (E. Kılınç, Yay. haz.). Ötüken. (Özgün metin 1912 yılında yayımlanmıştır)

Tahir Gürçağlar, Ş. (2011). Paratexts. Y. Gambier ve L. V. Doorslaer (Ed.), Handbook of Translation Studies (2. Cilt) (ss. 113-116). John Benjamins Publishing.

Tanpınar, A. H. (1997) 19'uncu Asır Türk Edebiyatı Tarihi (8. Bs.). Çağlayan Kitabevi.

Timur, T. (1991) Osmanlı-Türk Romanında Tarih, Toplum ve Kimlik. Afa Yayınları.

Toury, G. (2012). Çeviri normlarının doğası ve çevirideki rolü (A. Eker, Çev.). M. Rifat (Haz.), Çeviri Seçkisi II-Çeviri(bilim) Nedir? (ss. 149-164) (2. Bs.). Sel Yayıncılık. (Özgün metin 1995 yılında yayımlanmıştır)

Urgan, M. (2020). Ingiliz Edebiyatı Tarihi (13. Bs.). Yapı Kredi Yayınları.

Yıldız, G. (1998). Nâmık Kemâl'in" Salâhaddîn Eyyûbî" biyografisi: Öncü bir pan-İslamist metnin inşasına dair bazı gözlemler. IIImi Araştırmalar, (6), 271-287. 


\section{Ekler}

Ek 1- Maarif Kitaphanesi, 1934, Ön Kapak

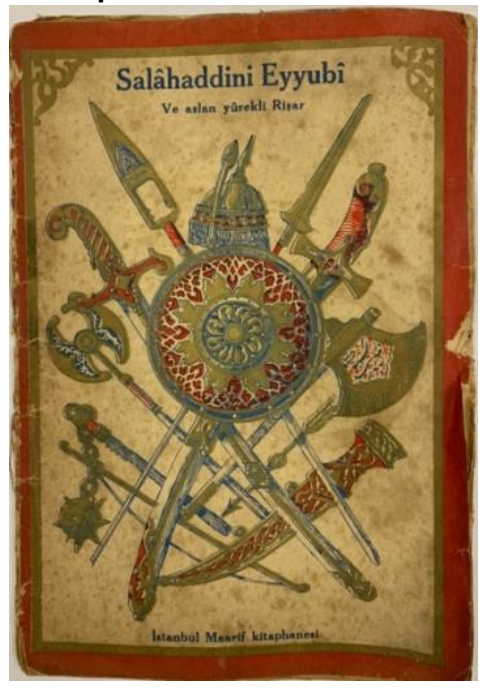

Ek 3- Maarif Kitaphanesi, 1953, Ön Kapak

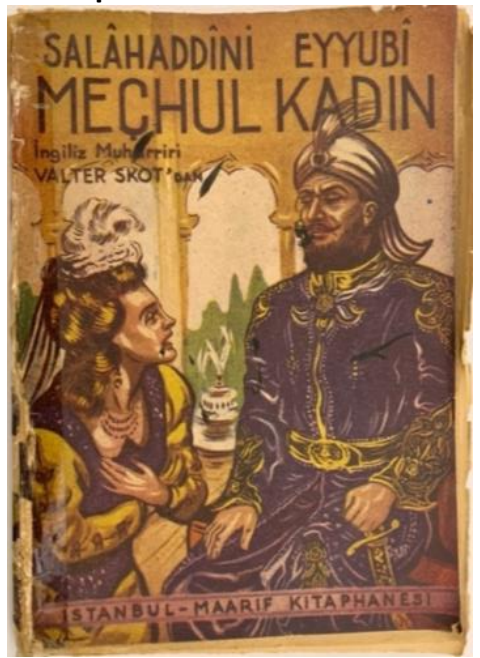

Ek 2- Maarif Kitaphanesi, 1934, Forma 8, Arka Kapak

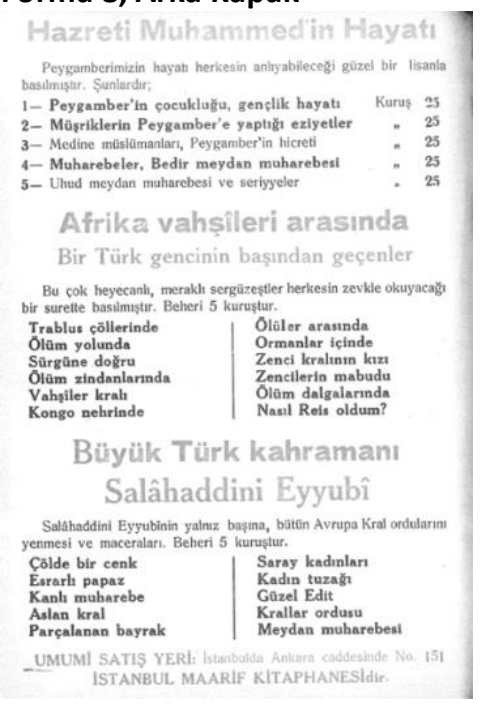

Ek 4- Maarif Kitaphanesi, 1953, İç Kapak

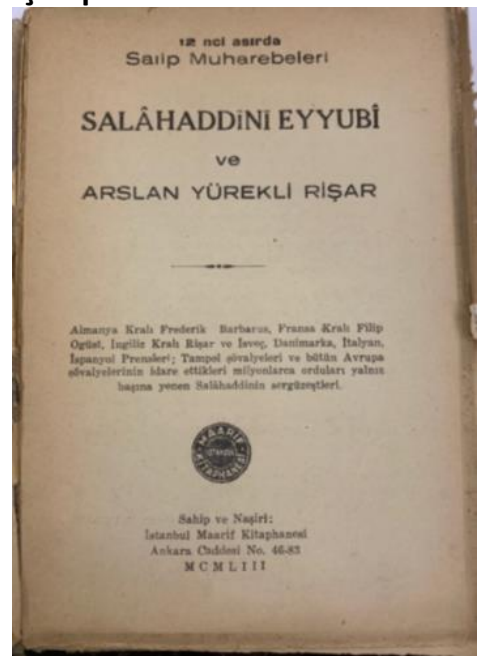


Ek 5- Maarif Kitaphanesi, 1964, Ön Kapak

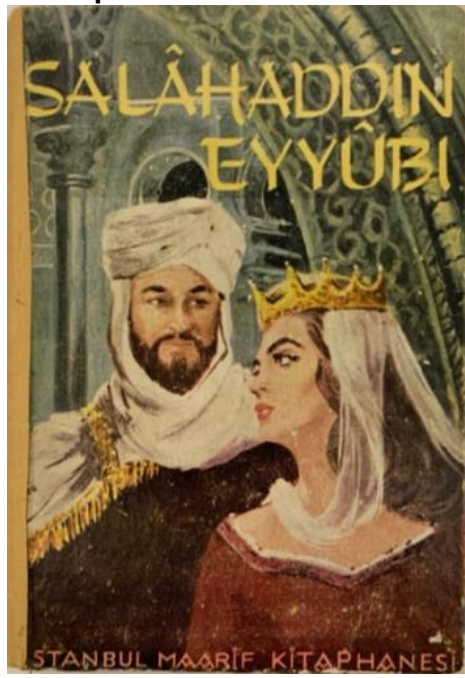

Ek 7- Maarif Kitaphanesi, 1964, İç Kapak

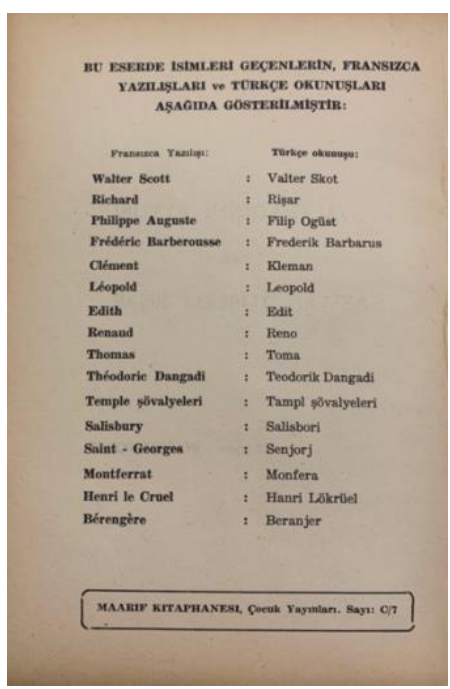

Ek 6- Maarif Kitaphanesi, 1964, İç Kapak

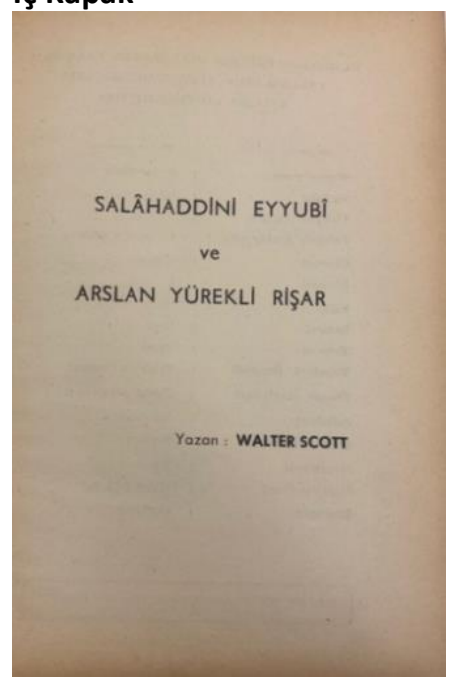

Ek 8-Timaş, 1995, Ön Kapak

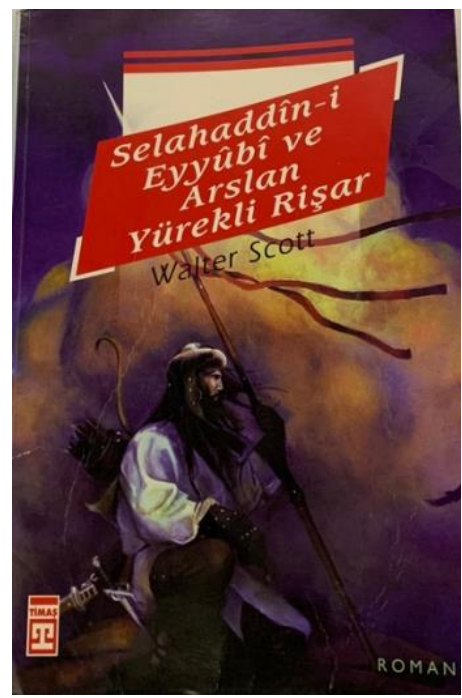


Diliçi Çeviriler, Yanmetinler ve Normlar Odağında Tarihsel Roman Çevirileri: The Talisman Örneği*

Ek 9-Ötüken, 2012, Ön Kapak

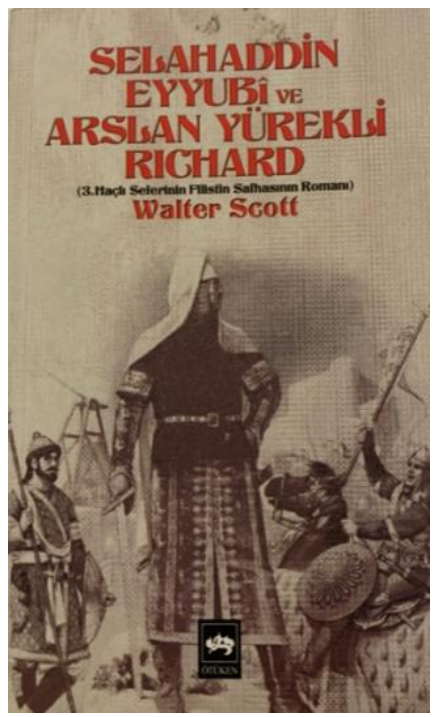

Ek 10-Ötüken, 2020, Ön Kapak

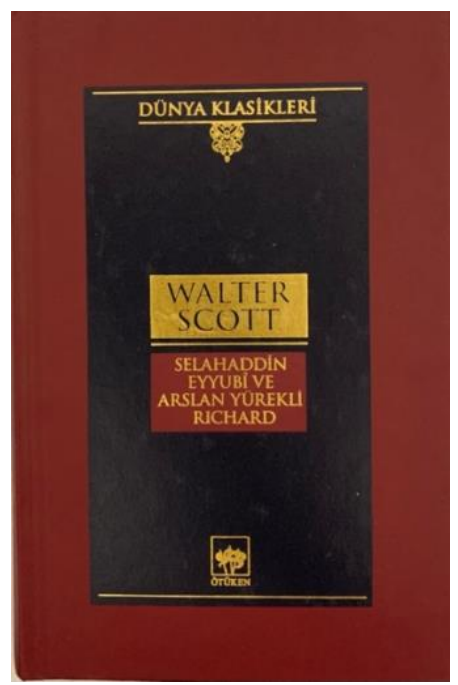

